\title{
The effect of mouthrinses against oral microorganisms
}

\author{
Ação dos enxaguatórios bucais contra \\ microrganismos bucais
}

\section{José Roberto Cortelli(a) \\ Raul Emilio de La Sotta Thénoux ${ }^{(b)}$}

\section{(a) Vice-Provost of Research, Department of Dentistry, Periodontics Research Division, University of Taubaté, Taubaté, SP, Brazil. \\ (b) Dean of Graduate studies, Universidad Central de Chile, Santiago, Chile.}

\author{
Corresponding author \\ José Roberto Cortelli \\ Pró-Reitoria de Graduação, Departamento \\ de Odontologia, Universidade de Taubaté \\ Rua dos Operários, 9 - Centro \\ Taubaté - SP - Brazil, CEP: 12020-240 \\ E-mail: cortelli@iconet.com.br
}

Received for publication on Nov 20, 2006 Sent for alterations on Dec 01, 2006 Accepted for publication on Jan 17, 2007

\begin{abstract}
This paper reviews the benefits of the use of antimicrobial mouthrinses for controlling dental biofilm. It is currently known that the human oral cavity is inhabited by approximately 600 to 700 different species of microorganisms, including bacteria, fungi and viruses, organized in biofilms. Biofilm accumulation represents the principal etiologic agent of oral diseases including caries and periodontal diseases. For that reason, prevention of biofilm accumulation has been shown to be associated with the control of diseases. Patient motivation and oral hygiene instruction are claimed to be a major factor influencing the degree of biofilm control. Therefore, mechanical home-care methods, including toothbrushing and flossing, represent the best way for patients to remove biofilm. For many patients, however, the elimination of all biofilm present in the oral cavity through home-care methods could be tedious and time-consuming. Additionally, some local conditions, including malpositioned teeth, presence of bridge-work or orthodontic appliances, among others, may render the mechanical control of biofilm especially difficult. Chemotherapeutic agents, including mouthrinses, could have a key role as adjuncts to daily home care, preventing and controlling supragingival plaque, gingivitis and oral malodor. Indeed, according to the ADA, the active ingredients of mouthwashes must demonstrate a therapeutic effect in vivo and in vitro to be classified as drugs. Several studies included in the present review have demonstrated the effectiveness of mouthrinses containing active ingredients such as chlorhexidine and essential oils in preventing and controlling both supragingival plaque and gingivitis, especially when used adjunctively to regular toothbrushing and flossing procedures.
\end{abstract}

Descriptors: Dental plaque; Oral hygiene; Anti-infective agents, local; Chlorhexidine.

Resumo: O propósito desta revisão foi mostrar os benefícios decorrentes do uso de enxaguatórios bucais no controle do biofilme dental. Atualmente sabe-se que a cavidade bucal dos humanos é habitada por aproximadamente de 600 a 700 espécies microbianas incluindo bactérias, fungos e vírus. Este aglomerado microbiano, atualmente definido como biofilme dental, é o principal agente etiológico das patologias bucais, incluindo cárie e doença periodontal. Logo, cuidados em relação ao controle destas doenças passam necessariamente pela eliminação ou redução do biofilme dental, incluindo métodos mecânicos adequados de higiene bucal e motivação do paciente. Todavia, a escovação dental e o uso de fio dental podem ser uma tarefa tediosa e consumir tempo exagerado para a rotina de muitos pacientes. Além disso, o controle mecânico do biofilme dental pode ser dificultado por fatores locais como uso de próteses e aparelhos ortodônticos, mau posicionamento dental, entre outros. Assim, o uso de enxaguatórios bucais, associado ao controle mecânico, pode ser incorporado rotineiramente aos cuidados de higiene bucal controlando terapêutica e preventivamente o biofilme supragengival, a gengivite e a halitose. De acordo com a ADA, agentes ativos vinculados aos enxaguatórios bucais devem demonstrar efeitos terapêuticos in vivo e in vitro para que estes sejam classificados como droga. Diferentes estudos incluídos nesta revisão demonstraram que a clorexidina e os óleos essenciais podem, em associação ao hábito regular de escovar os dentes e usar corretamente o fio dental, prevenir e controlar tanto o biofilme supragengival quanto as gengivites.

Descritores: Placa dentária; Higiene bucal; Antiinfecciosos locais; Clorexidina. 


\section{Introduction}

Since 400 years ago, when Anthony van Leeuwenhoek began using microscopes to study the human body, samples of dental plaque have been studied by several researches around the world. Nowadays, many studies confirm that the mouth is a complex ecosystem, which contains many microbial inhabitants including bacteria, viruses and fungi. These microorganisms grow in thin layers on the mouth's surfaces as teeth, tongue and mucosa membrane. Today, these layers are called biofilm.

Biofilms are spatially-organized communities of bacteria attached to a surface and enclosed in a matrix of extra-cellular material derived from both the component species and the environment. ${ }^{11}$ Biofilm exists to allow microorganisms to stick to surfaces and to multiply, representing the preferred method of growth for many bacterial species ${ }^{38}$ and providing a number of advantages to colonizing species. Protection from both competing microorganisms and environmental factors, such as host defense mechanisms, is the main advantage to colonizing species, including protection from potentially toxic substances such as chemicals and antibiotics. ${ }^{43}$

\section{Dental biofilm}

Biofilms are composed of microcolonies of bacterial cells non-randomly distributed in a shaped matrix or glycocalyx composed of water and aqueous solutes (exopolysaccharides, proteins, salts and cell material). It has been shown that there are specific associations between bacteria in dental biofilm. Inside biofilms one can observe the presence of water channels between microcolonies permitting the passage of nutrients and other agents throughout the biofilm, acting as a primitive circulatory system. Nutrients make contact with the attached microcolonies by diffusion from the water channel to the microcolony rather than from matrix. ${ }^{43}$

Mature dental plaque is inhabited by approximately 600 to 700 species of bacteria at $10^{8}-10^{9}$ bacteria per $\mathrm{ml}$ of saliva or $\mathrm{mg}$ of dental plaque..$^{21,40}$ It is plausible that the presence of bacteria represents the principal etiologic agent for several oral diseases including caries and periodontal diseases.
Caries is a disease caused by species such as Streptococcus mutans and Streptococcus sobrinus. ${ }^{27}$ In addition, bacterial species such as Porphyromonas gingivalis, Actinobacillus actinomycetemcomitans and Fusobacterium nucleatum have frequently been isolated from periodontal lesions and have been shown to be related to the onset and progression of periodontal disease..$^{42,44,46}$ On the other hand, microbial studies and clinical examinations have revealed that certain subgingival microorganisms are essential pathogenic factors in various types of human periodontal disease, so bacterial colonization may play an important role in the pathogenesis of periodontal disease. ${ }^{49}$

Prevention of biofilm accumulation has been shown to be associated with the control of diseases. ${ }^{3}$ Mechanical home-care methods have long been regarded as the best way for patients to remove biofilm. On the other hand, if oral hygiene is neglected, plaque growth reaches a maximum extent within 3-4 days, and biofilm is detected on almost all tooth surfaces. ${ }^{25}$ Patient motivation and oral hygiene instruction are claimed to be a major factor influencing the degree of biofilm control. ${ }^{39,47}$ Additionally, elderly patients, individuals presenting physical limitations, individuals using orthodontic appliances, bridge-work or presenting malpositioned teeth may find brushing and interdental cleaning especially difficult. ${ }^{10}$ Sometimes flossing also is widely time consuming and difficult for some patients. Since interdental hygiene is technically demanding, it is performed on a daily basis by only about $10 \%$ of the population. ${ }^{4,39}$

For all these different reasons, the regular use of antimicrobial mouthrinses may play a key role as adjuncts to brushing and flossing for preventing caries and gingivitis. ${ }^{8}$

In order for an active ingredient to be classified as a drug, the ingredient must demonstrate a therapeutic affect. The American Dental Association (ADA) acceptance program requires that over-the-counter toothpastes or mouthrinses with plaque control claims must show concomitant gingivitis and plaque reduction. The ADA confirms that if a product can only demonstrate a significant plaque reduction without a concomitant significant reduction in gingivitis, it will not be eligible for the seal of acceptance. ${ }^{2}$ 
Several studies have demonstrated the effectiveness of mouthrinses containing active ingredients such as chlorhexidine and essential oils in preventing and controlling both supragingival plaque and gingivitis, specially when used adjunctively to toothbrushing and flossing procedures. ${ }^{14,26,32}$ Both chlorhexidine's and essential oils' action time are equal, acting for 12 hours against biofilm. ${ }^{16}$ Pan et al. ${ }^{33}$ (2000) showed that bacterial phenotypes may change when the organisms go from a free floating state to a state where they are part of a biofilm. This change can result in altered susceptibilities to antimicrobial agents. Consequently, the efficacy of any antimicrobial mouthrinse depends not just on its microbicidal properties, that are often demonstrated in vitro, but also on its ability to penetrate the biofilm in vivo, ${ }^{31}$ therefore, we can confirm that this ability is what makes the difference. On the other hand, mouthrinses may not have efficacy in subgingival plaque and penetrate the subgingival area only minimally. ${ }^{5}$ Indeed, antimicrobial mouthrinses can not be expected to provide a therapeutic benefit by themselves in the treatment of periodontitis. ${ }^{36}$

Chlorhexidine attacks the bacterial cell membrane, causing leakage and/or precipitation of the cellular contents. ${ }^{15}$ Chlorhexidine may be considered the gold standard of chemotherapeutic agent for plaque and gingivitis control. ${ }^{1}$ The antibacterial activity of chlorhexidine is related to the cationic chlorhexidine molecule, which is rapidly attracted by the negatively charged bacterial cell surface. After adsorption, the integrity of the bacterial cell membrane is altered, which results in a reversible leakage of bacterial low molecular-weight components at low dosage ${ }^{12}$ or more severe membrane damage at higher doses. ${ }^{38}$ On the other hand, the adverse effects associated with chlorhexidine-containing mouthrinses have been related to extrinsic staining of the teeth and tongue, increased calculus formation and alteration of the taste sensation. ${ }^{48}$ Therefore, long-term use should be indicated and supervised by the dental professional.

Cetylpyridinium chloride is a quaternary ammonium classified as a cationic surface active agent. Cetylpyridinium chloride acts primarily by penetrating the cell membrane, which causes leakage of components in the cell, disruption of bacterial metabolism, inhibition of cell growth and cell death. ${ }^{6}$ However, because the positively charged hydrophilic region of cetylpyridinium chloride is critical to its antimicrobial activity, mouthrinse formulations should not contain ingredients that diminish or compete with the activity of this cationic group. ${ }^{48}$

Essential oils mouthrinses act killing microorganisms by disrupting their cell walls and by inhibiting their enzyme activity. ${ }^{15,24}$ Antimicrobial mouthrinses containing essential oils have a combination of thymol (0.064 percent), menthol (0.042 percent), eucalyptol (0.092 percent) and methyl salicylate (0.060 percent), as active ingredients. Listerine (Johnson \& Johnson Consumer \& Personal Products Worldwide, Morris Plains, New Jersey, USA) was tested for efficacy against oral bacteria as early as 1884 , by the legendary W. D. Miller. In his paper "Microorganisms of the human mouth", Miller stated that "Listerine has proved to be a very useful and active antiseptic". ${ }^{28}$ In 1929, an independent assessment of this essential oils mouthrinse showed it to have significant bactericidal activity against a variety of microorganisms and concluded it to be safe and effective.

The combination of essential oils has shown to be safe and effective as an over-the-counter antiplaque and antigingivitis agent. In an in vitro study, Ross et al..$^{41}$ (1989) showed that essential oils killed a wide range of microorganisms within 30 seconds in the presence of serum. Jenkins et al. ${ }^{19}$ (1994) showed that in an in vivo single rinse model, the use of an essential oils mouthrinse can significantly reduce the levels of recoverable salivary bacteria compared to a negative control rinse for periods of up to $5 \mathrm{~h}$. Although some experienced an initial burning sensation and biter taste, accommodation usually occurred in a few days and occasional tooth staining has been noted, but most clinical studies did not report this condition. ${ }^{48}$ Clinical studies have shown that essential oils retarded the formation of supragingival plaque and decreased the degree and severity of gingivitis. Additionally, the antimicrobial activity of the essential oil mouthrinses has been shown in saliva, ${ }^{13}$ in the gingival crevice, and on the dor- 
sal surface of the tongue. ${ }^{34,35}$ Plaque reduction has ranged from $20 \%$ to $34 \%$, and gingivitis reduction, from $28 \%$ to $34 \%$ when essential oils were used twice daily following tooth brushing. ${ }^{17,18}$

About 80 to $90 \%$ of the oral malodor originates locally in the mouth, and the bacterial overgrowth is the major etiological factor. In many cases, bacterial overgrowth is associated to poor oral hygiene, gingivitis and periodontitis, coating on the tongue, cavities and throat infections. ${ }^{29}$ Additionally, oral malodor affects from 40 to $50 \%$ of the population in different levels. ${ }^{30}$ In vitro, oral bacteria, as well as oral specimens such as saliva, plaque and tongue coatings, can produce the volatile sulfur compounds including hydrogen sulfide, methyl mercaptan, dimethyl sulfide, as well as compounds such as indoles and skatoles ${ }^{22}$ that contribute to the complex mixture of odorous molecules found in the exhaled air. In vivo, factors that support the growth of these bacteria will predispose a person to malodor. Examples include accumulation of food within pockets around the teeth, among the bumps at the back of the tongue, or in small pockets in the tonsils. ${ }^{23,37}$ Some studies have recognized that a diminished saliva flow also represents an important factor to malodor. A reduced saliva flow increases the concentration of bacteria in the mouth and worsens bad breath. ${ }^{45}$

The tongue represents a special place for the colonization of microorganisms, including dental and periodontal pathogens. Indeed, the tongue is colonized immediately after birth and anaerobic species can be detected prior to the eruption of teeth. Their

\section{References}

1. Addy M, Moran JM. Clinical indications for the use of chemical adjuncts to plaque control: chlorhexidine formulations. Periodontol 2000. 1997;15:52-4.

2. American Dental Association. Acceptance program guidelines. Chemotherapeutic products for control of gingivitis. Chicago: American Dental Association Council on Scientific Affairs; 1997.

3. Axelsson P, Lindhe J. The effect of a preventive programme on dental plaque, gingivitis and caries in schoolchildren. Results after one and two years. J Clin Periodontol. 1974;1(2):12638 . numbers and the presence of other anaerobes increase at the time of the primary eruption of teeth.

To eliminate oral malodor, home oral hygiene procedures are recommended to reduce accumulations of debris and the presence of bacteria. These procedures include tooth brushing and flossing, brushing the tongue or using a tongue scraper. Mouthrinses act against the malodor caused by oral bacteria when used as a complement to mechanical means, since by controlling bacteria it is possible to control malodor. The effects of mouthrinses could be due to thymol and eucalyptol, the volatile oils that have proven activity against bacteria. Kato et al. ${ }^{20}$ (1990) showed that bacterial counts plummet in as little as 30 seconds following a mouthrinse with thymol and eucalyptol. However, if the etiology of the oral malodor is related to periodontal disease, regular dental care is recommended to prevent or treat these pathologies. ${ }^{7,9}$

\section{Conclusions}

As biofilm accumulation represents the principal etiologic agent for oral diseases, including caries and periodontal diseases, prevention of biofilm accumulation, patient motivation and oral hygiene instruction are claimed to be the major factors influencing the degree of caries and periodontal diseases control. This review shows that mouthrinses containing active ingredients such as chlorhexidine and essential oils represent an important tool to prevent and control both supragingival plaque and gingivitis, especially when used adjunctively to toothbrushing and flossing procedures.

4. Bakdash B. Current patterns of oral hygiene product use and practices. Periodontol 2000. 1995;8:11-4.

5. Binder TA, Goodson JM, Socransky SS. Gingival fluid levels of acid and alkaline phosphatase. J Periodontal Res. 1987;22(1):14-9.

6. Block SS. Quaternary ammonium antimicrobial compounds. In: Block SS, editor. Disinfection, sterilization and preservation. $4^{\text {th }}$ ed. Philadelphia: Lea \& Febiger; 1991. p. 225-55.

7. Bollen CM, Rompen EH, Demanez JP. [Halitosis: a multidisciplinary problem] [Article in French]. Rev Med Liege. 1999;54(1):32-6. 
8. Bouwsma OJ. The status, future, and problems of oral antiseptics. Curr Opin Periodontol. 1996;3:78-84.

9. Brunette DM, Proskin HM, Nelson BJ. The effects of dentifrice systems on oral malodor. [published erratum in J Clin Dent 1998;9(4):inside front cov.] J Clin Dent. 1998;9(3):7682.

10. Ciancio SG. Use of mouthrinses for professional indications. J Clin Periodontol. 1988;15(8):520-3.

11. Costerton JW, Cook G, Lamont R. The community architecture of biofilms: dynamic structures and mechanisms. In: Newman HN, Wilson M, editors. Dental plaque revisited: Oral Biofilms in Health and Disease. Cardiff: Bioline; 1999. p. 5-14.

12. Denton GW. Chlorhexidine. In: Block SS, editor. Disinfection, sterilization and preservation. $4^{\text {th }}$ ed. Philadelphia: Lea \& Febiger; 1991. p. 274-89.

13. DePaola LG, Minah GE, Overholser CD, Meiller TF, Charles $\mathrm{CH}$, Harper DS et al. Effect of an antiseptic mouthrinse on salivary microbiota. Am J Dent. 1996;9(3):93-5.

14. DePaola LG, Overholser CD, Meiller TF, Minah GE, Niehaus C. Chemotherapeutic inhibition of supragingival dental plaque and gingivitis development. J Clin Periodontol. 1989;16(5):311-5.

15. Fine DH. Mouthrinses as adjuncts for plaque and gingivitis management. A status report for the American Journal of Dentistry. Am J Dent. 1988;1(6):259-63.

16. Fine DH, Furgang D, Sinatra K, Charles C, McGuire A, Kumar LD. In vivo antimicrobial effectiveness of an essential oil-containing mouth rinse $12 \mathrm{~h}$ after a single use and 14 days' use. J Clin Periodontol. 2005;32(4):335-40.

17. Fine JB, Harper DS, Gordon JM, Hovliaras CA, Charles CH. Short-term microbiological and clinical effects of subgingival irrigation with an antimicrobial mouthrinse. J Periodontol. 1994;65(1):30-6.

18. Gordon JM, Lamster IB, Seiger MC. Efficacy of Listerine antiseptic in inhibiting the development of plaque and gingivitis. J Clin Periodontol. 1985;12(8):697-704.

19. Jenkins S, Addy M, Wade W, Newcombe RG. The magnitude and duration of the effects of some mouthrinse products on salivary bacterial counts. J Clin Periodontol. 1994;21(6):397401.

20. Kato T, Iijima H, Ishihara K, Kaneko T, Hirai K, Naito Y et al. Antibacterial effects of Listerine on oral bacteria. Bull Tokyo Dent Coll. 1990;31(4):301-7.

21. Kazor CE, Mitchell PM, Lee AM, Stokes LN, Loesche WJ, Dewhirst FE et al. Diversity of bacterial populations on the tongue dorsa of patients with halitosis and healthy patients. J Clin Microbiol. 2003;41(2):558-63.

22. Kleinberg I, Westbay G. Oral malodor. Crit Rev Oral Biol Med. 1990;1(4):247-59.

23. Kleinberg I, Westbay G. Salivary and metabolic factors involved in oral malodor formation. J Periodontol. 1992;63(9):768-75.
24. Kubert D, Rubin M, Barnett ML, Vincent JW. Antiseptic mouthrinse-induced microbial cell surface alterations. Am J Dent. 1993;6(6):277-9.

25. Lang NP, Cumming BR, Loe H. Toothbrushing frequency as it relates to plaque development and gingival health. J Periodontol. 1973;44(7):396-405.

26. Lang NP, Hotz P, Graf H, Geering AH, Saxer UP, Sturzenberger OP et al. Effects of supervised chlorhexidine mouthrinses in children. A longitudinal clinical trial. J Periodontol Res. 1982;17(1):101-11.

27. Loesche WJ. Role of Streptococcus mutans in human dental decay. Microbiol Rev. 1986;50(4):353-80.

28. Mandel ID. Chemotherapeutic agents for controlling plaque and gingivitis. J Clin Periodontol. 1988;15(8):488-98.

29. Meningaud JP, Bado F, Favre E, Bertrand JC, Guilbert F. [Halitosis in 1999] [Article in French]. Rev Stomatol Chir Maxillofac. 1999;100(5):240-4.

30. Miyazaki H, Sakao S, Katoh Y. Oral malodor in the general population in Japan. In: Rosenberg M, ed. Bad breath: research perspectives; 1995. p. 119-36.

31. Ouhayoun JP. Penetrating the plaque biofilm: impact of essential oil mouthwash. J Clin Periodontol. 2003;30 Suppl $5: 10-2$.

32. Overholser CD, Meiller TF, DePaola LG, Minah GE, Niehaus C. Comparative effects of 2 chemotherapeutic mouthrinses on the development of supragingival dental plaque and gingivitis. J Clin Periodontol. 1990;17(8):575-9.

33. Pan P, Barnett ML, Coelho J, Brogdon C, Finnegan MB. Determination of the in situ bactericidal activity of an essential oil mouthrinse using a vital stain method. J Clin Periodontol. 2000;27(4):256-61.

34. Pianotti R, Pitts G. Effects of an antiseptic mouthwash on odorigenic microbes in the human gingival crevice. J Dent Res. 1978;57(2):175-9.

35. Pitts G, Brogdon C, Hu L, Masurat T, Pianotti R, Schumann P. Mechanism of action of an antiseptic, anti-odor mouthwash. J Dent Res. 1983;62(6):738-42.

36. Quirynen M, Teughels W, De Soete M, van Steenberghe D. Topical antiseptics and antibiotics in the initial therapy of chronic adult periodontitis: microbiological aspects. Periodontol 2000. 2002;28:72-90.

37. Reiss M, Reiss G. [Bad breath - etiological, diagnostic and therapeutic problems] [Article in German]. Wien Med Wochenschr. 2000;150(5):98-100.

38. Rolla G, Melsen B. On the mechanism of plaque inhibition by chlorhexidine. J Dent Res. 1975;54(spec No B):B57-62.

39. Ronis DL, Lang WP, Farghaly MM, Passow E. Tooth brushing, flossing and preventive dental visits by Detroit-area residents in relation to demographic and socioeconomic factors. J Public Health Dent. 1993;53(3):138-45.

40. Rosan B, Lamont RJ. Dental plaque formation. Microbes Infect. 2000;2(13):1599-607. 
41. Ross NM, Charles CH, Dills SS. Long-term effects of Listerine antiseptic on dental plaque and gingivitis. J Clin Dent. 1989;1(4):92-5.

42. Slots J, Listgarten MA. Bacteroides gingivalis, Bacteroides intermedius and Actinobacillus actinomycetemcomitans in human periodontal diseases. J Clin Periodontol. 1988;15(2):85-93.

43. Socransky S, Haffajee AD. Dental biofilms: difficult therapeutic targets. Periodontol 2000. 2002;28:12-55.

44. Tanner AC, Haffer C, Bratthall GT, Visconti RA, Socransky SS. A study of the bacteria associated with advancing periodontitis in man. J Clin Periodontol. 1979;6(5):278-307.

45. Tonzetich J. Production and origin of oral malodor: a review of mechanisms and methods of analysis. J Periodontol. 1977;48(1):13-20.
46. van Winkelhoff AJ, van Steenbergen TJ, de Graaff J. The role of black-pigmented Bacteroides in human oral infections. J Clin Periodontol. 1988;15(3):145-55.

47. Westfelt E, Nyman S, Socransky S, Lindhe J. Significance of frequency of professional tooth cleaning for healing following periodontal surgery. J Clin Periodontol. 1983;10(2):148-56.

48. Wu CD, Savitt E. Evaluation of the safety and efficacy of overthe-counter oral hygiene products for the reduction and control of plaque and gingivitis. Periodontol 2000. 2002;28:91105.

49. Yang HW, Huang YF, Chou MY. Occurrence of Porphyromonas gingivalis and Tannerella forsythensis in periodontally diseased and healthy subjects. J Periodontol. 2004;75(8):107783. 